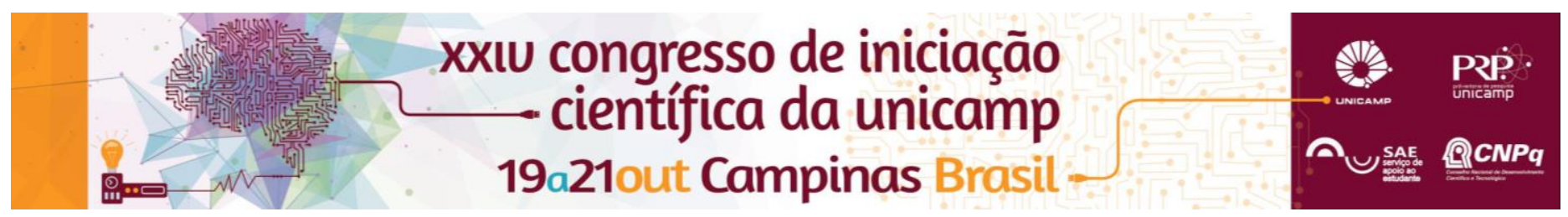

\title{
"Os Brothers do café": Uma análise sobre a circulação de objetos na colheita do café no município de Cabo Verde/MG.
}

\section{Lidia M. R. Torres*}

\begin{abstract}
Resumo
Essa pesquisa tem por objetivo analisar a circulação de diferentes bens materiais e simbólicos que transitam entre as/os trabalhadoras/es da colheita de café, no município de Cabo Verde/MG. Entre os trabalhadores da colheita há um fluxo intenso de pessoas e objetos, busca-se dessa maneira, analisar como se dá e quais os sentidos dessa circulação levando em consideração que ao olhar para a materialidade das coisas olhamos também para as relações sociais. Como já foi tratado por diversos autores, no mundo social objetos tangíveis e intangíveis estão imbricados. Este trabalho fundamentase na discussão de diversos autores da teoria antropológica para para mostrar os sentidos do que circula na colheita do café na Fazendo Ponto Alegre, sul de Minas Gerais.
\end{abstract}

\section{Palavras-chave:}

Trabalhadores rurais, circulação de objetos, Cabo Verde/MG.

\section{Introdução}

A principal fonte econômica de Cabo Verde/MG é o café. O núcleo de armazéns de café da cidade é o que mais entrega grãos para a Cooxupé, a maior Cooperativa de café do mundo. Por essas e outras Cabo Verde é popularmente conhecida como "terra do café".

Em época de colheita, faz-se necessária a importação de mão de obra de outros estados e cidades. Os migrantes que vão para a cidade muitas vezes acompanhados das suas esposas, crianças pequenas e adolescentes, veem no lucro obtido através da colheita a possibilidade de melhores condições econômicas e sociais já que partem de regiões em que a taxa de pobreza e desemprego são elevadas, sendo o café, quase sempre a principal fonte de renda dessas pessoas. O lucro obtido na colheita permite a aquisição de bens materiais como motos, eletrodomésticos e eletrônicos.

A colheita motiva um fluxo intenso de pessoas e, pude perceber que entre essas redes, há também um trânsito simbólico e material de coisas e mercadorias.

$\mathrm{Na}$ fazenda Ponto Alegre, a comida dos migrantes é preparada somente por cozinheiros/as vindos das suas respectivas cidades, com alimentos típicos de onde vieram, como carne seca e farofa. Alguns migrantes me relataram que seus filhos/as engordaram na escola rural do município e que aproveitaram do plano de saúde oferecido na cidade para fazer tratamento dentário, por exemplo. Nos corredores de cafezais há circulação de palavras e ajudas, e neles também há diferenciações sociais. A máquina de colher café e as posições de hierarquia assumidas em campo podem funcionar como marcadores simbólicos de diferença. Há criação de vínculos sociais na colheita a partir dos objetos, os migrantes da fazenda, por exemplo, criaram uma camiseta para irem ao trabalho estampando o nome pelo qual se chamam e a relação de afetividade que criaram: "Os Brothers do café" (Figura 1).

Nessa pesquisa analiso a dinâmica dessas relações, buscando ressaltar e mapear as diferenciações sociais a partir da maneira pela qual os objetos são apreendidos e ressignificados pelos diversos atores sociais presentes na colheita do café, sendo que mercadores simbólicos de diferença como gênero, origem e faixa etária podem influenciar em tal dinâmica.
Figura 1. "Os Brothers do café"

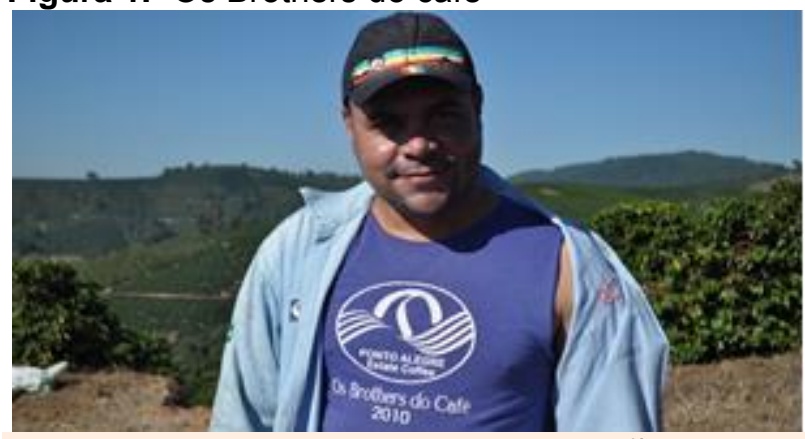

Resultados e Discussão

Para mapear o fluxo de objetos e pessoas envolvidas na colheita do café, em Cabo Verde, procurei realizar observação participante durante um trabalho de campo, registrando conversas, narrativas, práticas e comportamentos que me permitem mapear a circulação de bens materiais e simbólicos. Além da observação e registro no diário de campo procurei também desenvolver entrevistas e mobilizar dados sociais e teorias antropológicas que dialoguem com o tema.

\section{Conclusões}

$\mathrm{Na}$ colheita do café há um trânsito simbólico e material de objetos, pessoas, ajudas, palavras e coisas que são apreendidas e significadas. Afinal, como assinalado por Sigaud $(2007)^{2}$, no mundo social está tudo misturado. Ainda, o apontamento de Sahlins (2003, p.170) desenha essa pesquisa quando pondera que "nenhum objeto, nenhuma coisa é ou tem movimento na sociedade humana, exceto pela significação que os homens Ihe atribuem"1.

\section{Agradecimentos}

Á PRP/FAEPEX (Fundo de Apoio ao Ensino Pesquisa e Extensão) da Unicamp por financiar e tornar possível este trabalho.

${ }^{1}$ SAHLINS, Marshall David. "La Pensee Bourgeoise". In: Cultura e Razão Prática. Rio de Janeiro, RJ: Zahar, 2003.

2 SIGAUD, Lygia. "Se eu soubesse: as dívidas, os dons e suas equivalências", Revista Ruris, vol. 1 (2). 2007. 